УДК 657(100)

\title{
ОСОБЛИВОСТІ БУХГАЛТЕРСЬКОГО ФІНАНСОВОГО ОБЛІКУ У СПОЛУЧЕНИХ ШТАТАХ АМЕРИКИ, КИТАЙСЬКІЙ НАРОДНІЙ РЕСПУБЛІЦІ ТА ЄВРОПЕЙСЬКОМУ СОЮЗІ
}

\section{FEATURES OF FINANCIAL ACCOUNTING IN THE UNITED STATES OF AMERICA, THE CHINESE NATIONAL REPUBLIC AND THE EUROPEAN UNION}

\author{
Пилипенко Анастасія Володимирівна \\ студентка, \\ Національний технічний університет України \\ «Київський політехнічний інститут імені Ігоря Сікорського» \\ ORCID: https://orcid.org/0000-0001-8490-9278 \\ Решетнікова Юлія Олександрівна \\ студентка, \\ Національний технічний університет України \\ «Київський політехнічний інститут імені Ігоря Сікорського» \\ ORCID: https://orcid.org/0000-0002-3515-3838 \\ Лободзинська Тетяна Петрівна \\ кандидат економічних наук, доцент, \\ Національний технічний університет України \\ «Київський політехнічний інститут імені Ігоря Сікорського» \\ ORCID: https://orcid.org/0000-0001-5518-727X
}

\author{
Pylypenko Anastasia, Reshetnikova Yuliia, Lobodzynska Tetiana \\ National Technical University of Ukraine \\ "Igor Sikorsky Kyiv Polytechnic Institute"
}

\begin{abstract}
Стаття присвячена сутності та особливостям стандартів бухгалтерської фрінансової звітності, затверджених у Сполучених Штатах Америки, Китайській Народній Республіці та Європейському Союзі. Проаналізовано подібності та відмінності відносно Міжнародних стандартів фрінансової звітності. Досліджено алгоритми прийняття змін у відповідних національних стандартах, спричинені оновленням міжнародних. 3'ясовано історичні аспекти формування Китайських національних стандартів бухгалтерського обліку та ступінь впливу Загальноприйнятих принципів бухгалтерського обліку на функціонування ринку капіталу в США. Виокремлено основне джерело розбіжностей у фінансовій звітності країн-учасниць ЄС. Виявлено наслідки використання різних методів оцінки вартості активів, затверджених у кожній з досліджуваних територіальних одиниць, на фрінансовий результат діяльності підприємств.

Ключові слова: бухгалтерський облік, бухгалтерська звітність, стандарти бухгалтерської звітності, фрінансова звітність, CAS, GAAP, IFRS.

Статья посвящена сути и особенностям стандартов бухгалтерской фринансовой отчетности, утвержденных в Соединенных Штатах Америки, Китайской Народной Республике и Европейском Союзе. Проанализированы их сходства и различия в соответствии с Международными стандартами фринансовой отчетности. Исследованы алгоритмы принятия изменений в соответствующих национальных стандартах, вызванные обновлением международных. Установлены исторические аспекты формирования Китайских национальных стандартов бухгалтерского учета и степень влияния Общепринятых принципов бухгалтерского учета на фрункционирование рынка капитала в США. Выделен основной источник разногласий в фринансовой от-
\end{abstract}


четности стран-участниц ЕС. Выявлены последствия использования различных методов оценки стоимости активов, утвержденных в каждой из изучаемых территориальных единиц, на фринансовый результат деятельности предприятий.

Ключевые слова: бухгалтерский учет, бухгалтерская отчетность, стандарты бухгалтерской отчетности, оринансовая отчетность, CAS, GAAP, IFRS.

The article is devoted to the main point and specific features of accounting standards in the United States of America, the People's Republic of China, and the European Union. They are compared with the International Financial Reporting Standards to show the main differences and similarities between local and global accounting approaches. Globalization and international business development were the reasons for the importance of organizing the correct accounting process increase. In general, the principles of financial reporting differ in territorial regions. Therefore, doing research and analysis of accounting standards of the modern economy leading countries - USA, PRC, and $\mathrm{EU}$, is the relevant way to make an overview of the current process of accounting worldwide. It was proved that using the International Financial Reporting Standards is a versatile approach to report an enterprise's financial results. Each of the discovered countries sometimes approves these standards for international companies. Moreover, local Chinese, European, and American accounting standards are based on the IFRS ones. All of the IFRS updates usually are approved for recurrence of the national standards by certain governmental institutions, for instance, the Ministry of Finance in the People's Republic of China. However, gaining knowledge about the specifications for each country local accounting standards is crucial for completing the correct accounting activity. That is why, the historical background of the Chinese national accounting standards creation and the Generally Accepted Accounting Principles impact on the USA capital market are clarified. The main reason for the financial statements discrepancies in EU countries has been identified. In addition, the consequences of using different methods of estimating the assets' value, approved in each of the discovered countries, on the financial result of enterprises are revealed. Overall, the article consists of the detailed characteristics of the law and procedure differences in financial accounting reporting in the United States of America, the People's Republic of China, and the European Union.

Keywords: accounting, financial reporting, accounting standards, financial reporting, CAS, GAAP, IFRS.

Постановка проблеми. Відповідно до міжкультурних особливостей, що історично склались, принципи фрінансової звітності різняться від одного територіального регіону до іншого. Для фрормування загального уявлення про сучасний процес здійснення бухгалтерського фрінансового обліку доцільно розглянути та проаналізувати стандарти фрінансової звітності провідних країн сучасної економіки світу: Сполучених Штатів Америки (США), Китайської Народної Республіки (КНР) та Європейського Союзу (ЄС).

Аналіз останніх публікацій. Внаслідок глобалізації та активного поширення міжнародних зв'язків і бізнес-партнерств, унікальні риси бухгалтерського обліку у різних регіонах світу є актуальним об'єктом для вивчення серед українських та закордонних науковців. До прикладу, сучасники Мокринська 3. В., Сяо Ісінь, та Марко Пускотті досліджували особливості бухгалтерського фрінансового обліку в КНР, Ніколенко Б. - у США, Яцишин С. Р. у $Є$. Водночас, Антуан Бокуен виокремив відмінності між міжнародними і національними китайськими стандартами ведення фрінансової звітності, а Бренет С. - між міжнародними і американськими.

Постановка завдання. Завданням роботи $€$ дослідження сутності стандартів бухгалтерської фрінансової звітності США, КНР та ЄС, розмежування відмінностей та виокремлення національних особливостей орінансового обліку в зазначених країнах.

Виклад основного матеріалу. Принципи, правила, методи і стандарти облікових систем різних країн мають як схожість так і відмінності. Поширення зовнішньоекономічних зв'язків між різними країнами призводить до необхідності визначення особливостей бухгалтерського обліку та складання фрінансової звітності. Для проведення дослідження обрано стандарти бухгалтерського фрінансового обліку у Сполучених Штатів Америки, Китайській Народній республіці та Європейському Союзі.

«Загальноприйняті принципи бухгалтерського обліку» (GAAP) використовуються в США - це стандарти бухгалтерського обліку, затверджені закладами, що розробляють і встановлюють стандарти Фонду фрінансового обліку (FAF): Радою зі стандартів фрінансового обліку (FASB) і Радою з державних стандартів бухгалтерського обліку (GASB), які визначають вимоги і принципи підготовки фрінансової звітності [1].

Фонд фрінансового обліку (FAF) здійснює нагляд за адмініструванням, фрінансуванням, і призначенням Ради зі стандартів фрінансового обліку (FASB), яка встановлює стандарти фрінансового обліку та звітності для державних, приватних компаній, некомерційних організацій, і Ради зі стандартів (GASB), яка, в свою 
чергу, встановлює стандарти бухгалтерського обліку та фрінансової звітності для державних і місцевих органів влади США [1]. Ради зі стандартів несуть відповідальність за те, щоб GAAP залишалися еталоном високої якості фрінансової звітності, щоб інвестори, кредитори, постачальники капіталу та інші користувачі мали доступ до інформації, необхідної їм для прийняття обґрунтованих рішень.

Метою дотримання GAAP $є$ надання інформації про фрінансові результати діяльності підприємств для всіх зацікавлених сторін (стейкхолдерів) - кредиторів чи осіб, які надають або потенційно можуть надати ресурси 3 метою подальшого розвитку компаній. Фінансова звітність органів державного управління штату і місцевого самоврядування має додаткову мету: надати прозору інорормацію про свою діяльність для звітування перед платниками податків.

Серед основних національних американських принципів бухгалтерського фрінансового обліку виділяють наступні: визнання (які саме елементи мають зазначатись у фрінансових відомостях - активи, витрати, зобов'язання тощо), вимірність (якою $є$ кількість наявних елементів), презентування (необхідність відображення проміжних та фрінальних фрінансових результатів), розкриття інсрормації, яка доповнює і пояснює суми грошових коштів у фрінансових звітах [2].

Стандарти фрінансової звітності в рамках GAAP необхідні для есрективного фрункціонування ринків капіталу США. Місцеві організації та уряд мають можливість обмінюватися більш якісною фрінансовою інфрормацією про діяльність 3 метою отримання фрінансування, необхідного для найму робітників, модернізації інфрраструктури, інвестування у дослідження і розробки. Фінансова інфрормація, що надається інвесторам, кредиторам та іншим зацікавленим особам, має бути зрозумілою для всіх, повною і неупередженою. Ототожнення бухгалтерського обліку та фрінансової звітності також сприяє прийняттю більш раціональних фрінансових рішень - стейкхолдери мають можливість раціонально оцінити потенціал організації, яку планують проінвестувати. У свою чергу, уряди мають можливість продемонструвати громадянам і власникам облігацій власне вміння розпоряджатися державними ресурсами.

Виокремлюють такі особливості звітності американських компаній як [3]:

- відсутність чіткого регулювання термінів звітності: кожна публічна компанія зобов'язана публікувати щоквартальний звіт за встановленими нею термінами публікації;

- звітний період починається 3 десятого числа місяця, що настає за звітним кварталом (12-14 днів), і закінчується ближче до кінця другого місяця, наступного за звітним кварталом;

- звітний рік компанії не повинен збігатися 3 календарним, а кінець фрінансового року 3 кінцем кварталу або навіть місяця.

Міжнародні стандарти фрінансової звітності (IFRS) визнаються в Європейському союзі $(€ C)$, багатьох країнах Азії і Південної Америки, проте не в США. Комісія з цінних паперів і бірж не планує здійснювати перехід з GAAP на IFRS, але продовжить дотримуватись стратегії використання пунктів IFRS для доповнення фрінансової звітності США. Адже країнам, громадяни яких активно ведуть міжнародний бізнес, більш вигідно застосовувати IFRS [4].

GAAP дещо відрізняється від широко використовуваного IFRS, а основна відмінність між двома системами полягає в тому, що GAAP засновані на правилах, a IFRS - на принципах. Представники підприємств вимушені надавати набагато менше загальних деталей, дотримуючись IFRS, порівняно з GAAP. Отже, теоретична основа і принципи IFRS залишають більше можливостей для інтерпретації, містять широкі принципи обліку операцій у різних сорерах з обмеженою кількістю конкретних директив та умовними винятками із загальних директив [5, ст. 8-11]. 3 іншого боку, послідовні та інтуїтивно зрозумілі принципи IFRS більш логічні і, можливо, краще відображають економіку ділових операцій.

Розглядаючи різницю у звітних періодах, IFRS вимагає від інвестора використовувати найновішу фрінансову звітність асоційованого підприємства за методом власного капіталу, а GAAP, зі свого боку, допускає різницю у звітних періодах інвестора та об'єкта інвестування без застосування порогу «недоцільності». Американські стандарти бухгалтерського обліку не обмежують різницю між звітним періодом інвестора та об'єкта інвестицій; вимагають розкриття, а не коригування будь-яких істотних подій, що відбулися між датою фрінансової звітності компаній та інвестора [5, ст. 8-11].

Згідно з IFRS, фрінансова звітність інвестора складається 3 використанням єдиної облікової політики. В США основною вимогою є застосування інвестиційною організацією GAAP, щоб інвестор міг використовувати метод власного капіталу без коригування [5, ст. 19-20]. Окремі компанії використовують показники як GAAP, так і IFRS під час звітування про фрінансові 
результати. Проте, якщо звітність не складається відповідно до GAAP, інвесторам слід діяти обережно, відображаючи показники, що не відповідають GAAP, у фрінансовій звітності та інших відомостях [5, ст. 19-20].

Загалом, найбільша відмінність GAAP i IFRS зазначається у процесі обліку запасів. Правила IFRS забороняють використання методів обліку запасів в порядку черги, а правила GAAP допускають це. Обидві системи дозволяють використовувати метод «першим прийшов - першим пішов» (FIFO) і метод середньозваженої вартості. GAAP не допускає сторнування (виправлення) залишків запасів, тоді як IFRS дозволяє це при певних умовах.

Згідно з дослідженнями профресора Чжуннанського університету економіки і політики Го Даояна, викладеними у науковій праці «Історія розвитку бухгалтерської звітності», на території Китаю бухгалтерія мала виключно унікальні риси до 1900 року [6]. Згодом, із розвитком ринкової економіки, КНР перейняла західний досвід ведення фрінансової звітності, змінивши більшість національних попередньо усталених фрорм. Наприклад, 2 квітня 2010 р. Міністерство фрінансів Китаю затвердило «Дорожню карту зближення китайських положень і МСФЗ», що сприяло зростанню рівня справедливості відображення фрінансових результатів та міжнародної конкурентоспроможності національних підприємств [7].

Сучасні стандарти бухгалтерського обліку у Китайській Народній Республіці розробляються, видаються, та контролюються Міністерством фрінансів КНР на основі Міжнародних стандартів фрінансової звітності. IFRS окреслюють природу рахунку, тоді як рахунки CAS базуються на їх фрункціях. Загалом, варто визначити два базиси бухгалтерського обліку в Китаї, ними є: правові акти спеціального характеру (наприклад, розділ «Контроль за веденням бухгалтерської звітності та іншої господарської діяльності» у законі КНР від 04.09.1992 «Про управління стягування податків») та базові джерела правового регулювання (Конституція, цивільне і кримінальне право тощо) [8].

Єдиними принципами бухгалтерського обліку в Китаї $є$ наступні: правдиве, повне, і вчасне відображення результатів господарської діяльності у бухгалтерських розрахунках і звітності; збереження конкретного методу ведення бухгалтерського фрінансового обліку протягом одного звітного періоду; розрахунок майнових ресурсів на основі їхньої первісної вартості.
Факти порушення законодавства КНР у аспектах несплати, прострочення, чи недоплати податків передбачають стягнення 3 підприємства штрафрів у сумі до п'яти розмірів заборгованості при необхідності безпосередньо погасити зобов'язання [8]. Також, одним із унікальних аспектів, що базуються на менталітеті та усталених традиціях громадян Китаю, $є$ акцентування уваги на репутації людини. У бухгалтерській діяльності це відображається шляхом залякування бухгалтерів оприлюдненням їхньої особистості на всю країну, якщо підприємство, де вони працюють, не сплачує податки чи приховує справжні фрінансові результати. Китайська влада розробила авторський механізм для боротьби 3 неповним відображенням доходів компаній, що прагнуть зменшити своє податкове навантаження. Його сутність полягає в організації Податковою службою чекових лотерей для покупців, які отримують матеріальні призи, якщо номер отриманого від будь-якої покупки в країні чеку співпадає із номером розіграшу [8]. Тобто люди, зацікавлені реалізувати власну удачу, вимагають усюди чеки, і магазини вимушені фріксувати дійсні розміри всіх покупок, що сприяє максимізації надходжень до бюджету.

У Китайській Народній Республіці велику увагу приділяють чесності в усіх видах діяльності, а головне - у фрінансових питаннях: протидія корупції, стимулювання податкових надходжень, і сприяння прозорості фрінансової звітності, як зазначалось вище. Одним із аспектів досягнення таких цілей $є$ наближення національних стандартів ведення бухгалтерського обліку (CAS) до міжнародних (IFRS). CAS поділяються на 2 групи: Стандарти бухгалтерського обліку для підприємств (ASBE) i Стандарти бухгалтерського обліку для підприємств малого бізнесу (ASSBE) [9]. Із повного списку ASBE (41 стандарт) основними можна виокремити такі, як: Представлення фрінансової звітності (ASBE 30), Звіти про рух грошових коштів (ASBE 31), Запаси (ASBE 1), Постійні витрати (ASBE 4), Знецінення активів (ASBE 8), Дохід (ASBE 14) [10]. Їх не можна співвідносити із відповідними стандартами 3 IFRS, вони $€$ прикладами національних стандартів, що доповняють і деталізують міжнародні.

В узагальненому вигляді, основні відмінності CAS від IFRS можна зазначити за трьома аспектами: методи оцінки основних засобів, деталізація правил, та затримка впровадження IFRS [9]. По-перше, національними стандартами бухгалтерського обліку в 
КНР визнається оцінка основних засобів, що базується виключно на їх історичній вартості, а Міжнародними стандартами срінансової звітності - і за історичною вартістю, і шляхом переоцінки активів [9]. По-друге, у деяких випадках, кожен із двох стандартів має унікальні, більш детально прописані правила, відносно іншого. До прикладу, у Китаї розповсюдженою подією є злиття компаній, тому CAS передбачає першочергове проведення перерахунку відповідних орінансових показників обох суб'єктів господарювання перед їх об'єднанням [9]. Натомість деталізація витрат на оплату праці характерна тільки для IFRS. По-третє, після внесення доповнень до статей IFRS, Міністерство фрінансів КНР проводить засідання для прийняття рішення 3 приводу здійснення відповідних змін у CAS. Однак, виникають випадки, коли оновлення відкладаються на невизначений термін або взагалі не відбуваються, тоді збільшується кількість розбіжностей між CAS та стандартами бухгалтерського обліку в інших країнах світу, які оперативно затвердили корективи IFRS на національному рівні [9].

Більш конкретно варто відзначити наступні особливості CAS порівняно 3 IFRS [11]:

- у KHP, згідно із CAS, звітний період починається 1 січня кожного року;

- у CAS використовується місцева валюта, а операції в іноземній валюті конвертуються в еквівалентну суму юанів за офріційним курсом;

- за CAS, подвійний запис заповнюється лише в юанях;

- CAS має вимоги щодо розкриття особистості ділових партнерів;

- CAS може вимагати звітів про непрямі грошові потоки та пояснень щодо справедливості цих операцій.

У зв'язку із глобалізацією, розвитком міжнародного бізнесу, та потенціалом китайського ринку, бізнесмени активно цікавляться деталями здійснення інвестиційної діяльності В КНР. Зокрема, фрінансову звітність іноземні інвестовані підприємства (FIE) можуть готувати відповідно до інших стандартів бухгалтерського обліку або іншими мовами для цілей глобальної консолідації. Однак, китайська влада визнаватиме та прийматиме лише ті рахунки, які підготовані на основі китайських стандартів бухгалтерського обліку китайською мовою [12].

Відповідно до правил $€ С$, компанії, що котируються на біржі, повинні складати свою консолідовану фрінансову звітність відповідно до Міжнародних стандартів фрінансової звіт- ності - IFRS. Таке затвердження сприяє злагодженій, чіткій, та уподібненій фрінансовій звітності компаній, незалежно від країни, де вони локалізуються. Загалом, усі суб'єкти господарювання, що здійснюють підприємницьку діяльність на територіях країн-учасниць $Є С$, зобов'язані складати фрінансову звітність 3 метою відстеження і надання реального та достовірного уявлення про своє фрінансове становище [13].

Якщо фрінансова звітність не складається відповідно до IFRS, то підприємства, які фрункціонують в ЄС, незалежно від їх розміру, повинні складати річні звіти, що містять баланс, звіт про прибутки та збитки, а також, декілька приміток до фрінансової звітності, та подавати їх до відповідного національного реєстру підприємств.

Правила, яких повинні дотримуватися компанії при складанні фрінансової звітності, викладені в Директиві 2013/34/ЄС, відомій як «Директива про бухгалтерський облік». її метою $€$ гармонізація національних вимог до подання, змісту, аудиту, публікації річної або консолідованої фрінансової звітності, презентації та змісту управлінської звітності, а також відповідальності керівництва. Директива про бухгалтерський облік також спрямована на зменшення адміністративного навантаження на малі та середні підприємства, адже передбачає для них спрощений режим звітності [14]. Згідно з регламентом (ЄС) № 1606/2002 усі компанії, залучені на біржі, готують консолідовану фрінансову звітність відповідно до IFRS. При цьому країни-учасниці ЄС можуть додатково поширити необхідність застосування IFRS на річні звіти чи звіти компаній, що не котируються на біржі [13].

IFRS укладаються незалежним органом, що базується в Лондоні, Радою 3 міжнародних стандартів фрінансової звітності (IASB). Тому, оновлені стандарти з IFRS, перед набуттям чинності у $€ C$, потребують обов'язкового затвердження в певній послідовності [13]. Для початку, правління IFRS приймає новий стандарт, поправку до існуючого стандарту або тлумачення стандарту. В подальшому, Європейська консультативна група з фрінансової звітності (EFRAG) надає свої рекомендації Комісії для затвердження. Комісія, в свою чергу, визначається 3 прийняттям нового стандарту, тлумачення або поправки, готує пропозицію щодо резолюції та подає ії̈ до Комітету з регулювання бухгалтерського обліку (ARC). Якщо висновок ARC позитивний, Комісія подає пропозицію щодо резолюції до Європейського Парламенту та Ради на 
тримісячний період розгляду або, якщо Європейський Парламент чи Рада не заперечують, рішення приймає Комісія [15].

Стандарти IFRS, прийняті в $€ C$, необхідні для консолідованої фрінансової звітності всіх європейських компаній та бірж. Окремі держави-члени ЄС мають можливість вимагати дотримання IFRS, прийнятих у $€ C$, для таких суб'єктів господарювання, як: невеликих бірж, які не зосереджені на регульованих ринках; окремих срінансових звітів деяких чи усіх компаній, цінними паперами яких торгуються на регульованому ринку; консолідованих фрінансових звітів усіх або деяких компаній, цінні папери яких не торгуються на регульованому ринку [14]. Європейська Комісія регулярно оцінює рішення країн-учасниць ЄС щодо використання вищезазначених опцій.

Основним джерелом розбіжностей у фрінансовій звітності країн-учасниць $€ C €$ фріксування податкових відрахувань. Податкове регулювання в країні залежить від її політики та цілей місцевого уряду, а не регулюється міжнародним органом, як у випадку 3 IFRS. У зв'язку із цим, у Європі існують різні ініціативи щодо гармонізації податкового регулювання. Спільна база оподаткування для податку на додану вартість - це нещодавня ініціатива, в рамках якої компанії, що працюють у різних країнах $€ C$, подібним чином підсумовують свої витрати та доходи з метою розрахунку консолідованого прибутку. В подальшому, надходження від сплати податку будуть розподілені між країнами залежно від рівня їхньої активності [16].

Розглядаючи фрінансову звітність в різних юрисдикціях, слід враховувати такі аспекти, як: фрормат фрінансового звіту в різних країнах та спеціальні вимоги, які можуть відрізнятися за складністю; відмінності в підходах до бухгалтерського фрінансового обліку. Зазвичай, сорерами різниці є валютні курси, оцінка запасів, основні засоби та методи розрахунку амортизації [16].
Загалом, Європейський Союз на міжнародному рівні підтримує принцип єдиного набору світових стандартів бухгалтерського обліку для компаній, що котируються на біржі, і співпрацює $з$ компетентними органами по всьому світу, щоб сприяти прийняттю IFRS. Оскільки деякі з ключових торгових партнерів Союзу ще не прийняли IFRS, ЄC приймає стандарти бухгалтерського обліку деяких країн, що не є його членами, як еквівалентні IFRS, щоб полегшити транскордонний допуск до торгівлі [17].

Продемонструвати різницю між CAS (KHP), GAAP (США), та IFRS (ЄС) доцільно на прикладі оцінки активів. У КНР і США вона ґрунтується на історичній вартості активів. Переоцінка активів в Китаї не дозволена і допускається лише у разі об'єднання компаній, відповідно до GAAP. Водночас, IFRS допускають подібну переоцінку активів на основі їхньої історичної або справедливої вартості, а тому і країни Європейського Союзу перейняли цю практику. Загалом, за методом справедливої вартості активів переоцінку необхідно проводити регулярно, відповідно до змін їхньої ринкової вартості.

Вищезазначені відмінності можуть призвести до розбіжностей у представленні позиції бізнесу. Тобто, якщо певна компанія, використовуючи ASBE (Китай) чи GAAP (США), витратила 1000 од. місцевої валюти на обладнання на початку року, а 31 грудня того ж року ринкова ціна цього обладнання зросла на 500 од. місцевої валюти, то вона відобразить витрати на амортизацію у 100 од. місцевої валюти у своєму звіті про прибутки та збитки, що є вирахуванням з чистого прибутку компанії. На відміну від цього, відповідно до IFRS чи умовно IFRS (ЄC), компанія матиме додатковий прибуток від переоцінки у розмірі 500 од. місцевої валюти, який надходитиме до її іншого сукупного доходу (табл. 1).

Висновки. Отже, підсумовуючи результати проведеного дослідження, можна зробити наступні висновки. По-перше, стан-

Таблиця 1

Вплив методу оцінки вартості обладнання, затвердженому у КНР, США, чи ЄС, на фінансовий результат діяльності компанії

\begin{tabular}{|c|c|c|c|}
\hline & $\begin{array}{c}\text { Ціна обладнання на } \\
\text { початку року, } \\
\text { од. місцевої валюти }\end{array}$ & Зміни, що відбулись & $\begin{array}{c}\text { Ціна обладнання } \\
\text { на кінець року, } \\
\text { од. місцевої валюти }\end{array}$ \\
\hline США & 1000 & «Знецінення» на 100 од. & 900 \\
\hline ЄС & 1000 & $\begin{array}{c}\text { Підвищення справедливої } \\
\text { ціни на 500 од. }\end{array}$ & 1500 \\
\hline КНР & 1000 & «Знецінення» на 100 од. & 900 \\
\hline
\end{tabular}


дарти бухгалтерського фрінансового обліку у Сполучених Штатів Америки, Китайській Народній республіці та Європейському Союзі здебільшого відповідають Міжнародним стандартам фрінансової звітності (IFRS). По-друге, національні особливості кожної 3 проаналізованих країн та країн-членів економічно-політичного союзу, частково збігаються (підхід до оцінки вартості активів у США і КНР) та широко різняться (порядок обліку запасів у США, початок звітного періоду виключно 1-го січня кожного року в КНР, та значний вплив податкової системи у кожній з країн-учасниць ЄС на звітність підприємств). Виявлено, що IFRS $€$ найбільш універсальними стандартами ведення фрінансової звітності, проте для коректного здійснення бухгалтерського обліку та відображення фрінансових результатів компаній, необхідно детально вивчати відповідні принципи та стандарти у конкретній країні, де підприємство провадить свою діяльність.

\section{СПИСОК ВИКОРИСТАНИХ ДЖЕРЕЛ:}

1. The importance of GAAP. URL: https://www.accountingfoundation.org/cs/Satellite?c=Page \&cid=1176164538 898\&pagename=Foundation\%2FPage\%2FFAFBridgePage\#section_2

2. About GAAP. URL: https://www.accountingfoundation.org/cs/Satellite?c=Page\&cid=1176164538898\&pagena me=Foundation $\% 2 F P a g e \% 2 F F A F B$ ridgePage

3. Николенко Б. Бухгалтерская отчетность компаний в США. 2021. URL: https://internationalwealth.info/ accountancy-abroad/buhgalterskaja-otchetnost-kompanij-v-ssha/

4. IFRS. URL: https://www.ifrs.org/use-around-the-world/use-of-ifrs-standards-by-jurisdiction/

5. Securities and Exchange Commission Comparison of U.S. GAAP and IFRS. URL: https://www.sec.gov/ spotlight/globalaccountingstandards/ifrs-work-plan-paper-111611-gaap.pdf

6. Сяо Исинь, Титова Н.Ю. Исторические аспекты развития бухгалтерского учета в Китае. Владивостокский государственный университет экономики и сервиса. URL: https://portfolio.vvsu.ru/files/BE81470012E6-4771-870E-70283B9E2477.pdf

7. Мокринська 3.В. Особливості бухгалтерського обліку в Китаї. Національний авіаційний університет. URL: http://www.ej.kherson.ua/journal/economic_10/46.pdf

8. Бабаева 3.Ш. Система бухгалтерского учета в Китае: опыт государственного регулирования. Дагестанский государственный университет. URL: https://cyberleninka.ru/article/n/sistema-buhgalterskogo-uchetav-kitae-opyt-gosudarstvennogo-regulirovaniya

9. Accounting Standards in China. URL: https://www.tradecommissioner.gc.ca/china-chine/accountingcomptables.aspx?lang=eng

10.Marco Pasquotti. Chinese Accounting Standards. 2018. URL: https://www.linkedin.com/pulse/\%E4\%B8\%AD\%E5 \%9B\%BD\%E4\%BC\%9A\%E8\%AE\%A1\%E5\%87\%86\%E5\%88\%99-chinese-accounting-standards-marco-pasquotti

11.Antoine Boquen. China Accounting Standards CAS and IFRS. New Horizons. 2021. URL: https://nhglobalpartners.com/china-accounting-standards-cas-ifrs/

12. Accounting and accounting rules in China. 2021. URL: https://www.nordeatrade.com/en/explore-new-market/ china/accounting

13. EU rules on financial information disclosed by companies. URL: https://ec.europa.eu/info/ business-economy-euro/company-reporting-and-auditing/company-reporting/financial-reporting_en

14. European Union. URL: https://www.ifrs.org/use-around-the-world/use-of-ifrs-standards-by-jurisdiction/viewjurisdiction/european-union/

15. European Financial Reporting Advisory Group. URL: https://www.iasplus.com/en/resources/regional/efrag

16. European Union: Financial reporting differences in Europe. URL: https://www.mondaq.com/uk/accountingstandards/733360/financial-reporting-differences-in-europe

17. IFRS Retrieved from: https://www.ifrs.org/

18. Weining Hu. China's Accounting Standards: Chinese GAAP vs. US GAAP and IFRS. Dezan Shira \& Associates. 2017. URL: https://www.china-briefing.com/news/china-gaap-vs-u-s-gaap-and-ifrs/

\section{REFERENCES:}

1. The importance of GAAP. Retrieved from: https://www.accountingfoundation.org/cs/Satellite?c= Page\&cid=1176164538898\&pagename=Foundation\%2FPage\%2FFAFBridgePage\#section_2

2. About GAAP. Retrieved from: https://www.accountingfoundation.org/cs/Satellite?c=Page \&cid=11761645 38898\&pagename=Foundation\%2FPage\%2FFAFBridgePage 
3. Nikolenko B. (2021) Bukhgalterskaya otchetnost' kompaniy v SSHA [Financial statements of companies in the United States of America]. Retrieved from: https://internationalwealth.info/accountancy-abroad/buhgalterskaja-otchetnost-kompanij-v-ssha/

4. IFRS. Retrieved from: https://www.ifrs.org/use-around-the-world/use-of-ifrs-standards-by-jurisdiction/

5. Securities and Exchange Commission Comparison of U.S. GAAP and IFRS. Retrieved from: https://www.sec.gov/ spotlight/globalaccountingstandards/ifrs-work-plan-paper-111611-gaap.pdf

6. Xiao Yixin, Titova N. Istoricheskiye aspekty razvitiya bukhgalterskogo ucheta v Kitaye [Historical aspects of the development of accounting in China]. Vladivostokskiy gosudarstvennyy universitet ekonomiki i servisa - Vladivostok State University of Economics and Service. Retrieved from: https://portfolio.vvsu.ru/files/BE814700-12E6-4771870E-70283B9E2477.pdf

7. Mokrinska Z. Osoblyvosti bukhhalters'koho obliku v Kytayi [Accounting features in China]. Natsional'nyy aviatsiynyy universytet - National Aviation University. Retrieved from: http://www.ej.kherson.ua/journal/economic_10/46.pdf

8. Babaeva Z. Sistema bukhgalterskogo ucheta $v$ Kitaye: opyt gosudarstvennogo regulirovaniya [Accounting system in China: state regulation experience]. Dagestanskiy gosudarstvennyy universitet - Dagestan State University. Retrieved from: https://cyberleninka.ru/article/n/sistema-buhgalterskogo-ucheta-v-kitae-opyt-gosudarstvennogo-regulirovaniya

9. Accounting Standards in China. Retrieved from: https://www.tradecommissioner.gc.ca/china-chine/accounting-comptables.aspx?lang=eng

10. Marco Pasquotti (2018). Chinese Accounting Standards. Retrieved from: https://www.linkedin.com/pulse/ \%E4\%B8\%AD\%E5\%9B\%BD\%E4\%BC\%9A\%E8\%AE\%A1\%E5\%87\%86\%E5\%88\%99-chinese-accounting-standards-marco-pasquotti

11. Antoine Boquen (2021). China Accounting Standards CAS and IFRS. New Horizons. Retrieved from: https://nhglobalpartners.com/china-accounting-standards-cas-ifrs/

12. Accounting and accounting rules in China (2021). Retrieved from: https://www.nordeatrade.com/en/explorenew-market/china/accounting

13. EU rules on financial information disclosed by companies. Retrieved from: https://ec.europa.eu/info/business-economy-euro/company-reporting-and-auditing/company-reporting/financial-reporting_en

14. European Union. Retrieved from: https://www.ifrs.org/use-around-the-world/use-of-ifrs-standards-by-jurisdiction/view-jurisdiction/european-union/

15. European Financial Reporting Advisory Group. Retrieved from: https://www.iasplus.com/en/resources/ regional/efrag

16. European Union: Financial reporting differences in Europe. Retrieved from: https://www.mondaq.com/uk/ accounting-standards/733360/financial-reporting-differences-in-europe

17. IFRS. Retrieved from: https://www.ifrs.org/

18. Weining Hu (2017). China's Accounting Standards: Chinese GAAP vs. US GAAP and IFRS. Dezan Shira \& Associates. Retrieved from: https://www.china-briefing.com/news/china-gaap-vs-u-s-gaap-and-ifrs/ 